\title{
Possible weaknesses of the solvency ratios of the Basel Accords
}

\author{
Authors \\ J. Vicente Fruet-Cardozo (University of Cordoba, Spain) \\ José Ramón Millán de la Lastra (University of Cordoba, Spain) \\ Juan Antonio Cañas Madueño (University of Cordoba, Spain)
}

\begin{abstract}
A strong, sturdy and stable banking system is a basic condition for how the engine of the economy of a country works, and thus to support sustainable economic growth. In theory, the Basel Accords I, II and III aim to achieve these characteristics of strength, endurance and stability for the financial system. However, in the light of the financial crisis of the past 20 years, there are doubts about the effectiveness that the Basel agreements had to support banks during financial storms over the years of its implementation.
\end{abstract}

Keywords - Stress test; Basel Accords; Solvency, leverage and assets financed by equity ratios; Spanish banks; Capital level 1; Risk weighted assets (RWA); Capital increase

\section{Introduction}

Banks, which have a sensitive role in the economic scenario of a country, are companies that should have the same rights and obligations as all others. But often this is not the case, because when they have problems, sometimes for poor management, they are helped - "rescued" - with taxpayers' money. This often occurs in many parts of the world, including in our beloved Europe. Rescue situations could be avoided in many cases, if the capital of financial institutions was used to set up a foundation able to withstand the economic storms simultaneously with the requirements of creditors. However, in the current situation, even with the Basel Accords III, we have serious doubts as to whether the parameters applied to measure the solvency ratios are adequate.

This article is focused on the results of stress tests carried out on the Spanish banks in November 2014. And faced with the questionable "approved" result obtained, specifically related to the solvency ratio, a more reliable proposal is presented here as an alternative solution. It concerns the gradual increase of additional capital in a scenario over five years, from 2015 2019 , aiming to provide a real solvency to face the economic and financial ups and downs that will occur in the future.

\section{The Basel Accords}

A brief summary of the three Basel Accords is presented below.

\subsection{Basel Accord I}

The first Basel Committee was held in 1975. At its creation it was attended by ten presidents of the central banks of the socalled Group of Ten, G $10^{1}$.

${ }^{1}$ The G10 is the group of countries that participates in the General Arrangements to Borrow (GAB). The GAB was established in 1962 when the governments of eight member countries of the International Monetary Fund (IMF) Belgium, Canada, France, Italy, Japan, Netherlands, United Kingdom and the United States and the central banks of two others, Germany and Sweden, agreed to provide more resources to increase the amount of money available to the IMF loans to
Basel I set a minimum capital that banks must have on its Risk Weighted Assets (RWA). At that time, the solvency ratio required for banks was a capital to RWA $\square 8 \%$, to facilitate the absorption of losses from credit risk. The Basel I structure can be seen in Figure 1.

\subsection{Basel Accord II}

In 2004, the Committee published a revision of the Agreement of 1988 which established procedures for the calculation of the RWA. It also provided that banks should have the possibility to apply risk ratings based on their own models. This second agreement did not alter the basic elements of Basel I, such as (i) the solvency ratio, which remained at $8 \%$, and (ii) the definition of capital, which did not change the aggregate level of the capital requirements. The calculation of the solvency ratio of Basel I set out in Figure 2.

It may be noted that Basel II does not change the numerator of the solvency ratio as defined in Basel I. What this event changed was the denominator in what it referred to as the calculation of risk weighted assets. Therefore, one of the aims of this new agreement was to adapt the level of the regulatory capital to the real situation of each bank. Later, it was found that there were huge differences of criteria in the interpretation and implementation of agreements by each bank. The main differences between Basel I and Basel II are summarized in Figure 3.

The rules of market risk are not modified, but the credit risk. It also introduced a new operational risk that had not been contemplated. Basel II represented a major challenge, both for banks and for their supervisors. For the banks, because, for the first time were allowed to use their own credit risk models and operate to determine the minimum regulatory capital they needed. For supervisors, because they were faced with a new operational framework, and therefore, unknown so far, compared to traditional monitoring practices. Basel II structure is shown in Figure 4.

The Basel II framework was based on three pillars and the relationship among them was one of the factors relevant to the agreement and involved a triple guarantee: (i) the definition of a more ambitious and complex regulation, (ii) supervisory review of this regulation, and (iii) verification of their implementation by the market.

It was expected that the structure of the three pillars would prevent any problems with the banks. However, the global financial crisis of 2007, though it began before the coming into force of Basel II, laid bare the weaknesses of the new agreement. Among these are included: (a) the "generous" definition of capital, (b) the deficiency of the requirements reflected in the excessive leverage in the financial system, (c) the shortage noticeable in securities and the definition of market risk, (d) little respect for the supervisory guidelines on good governance and risk management, and (e) the ineffectiveness of the

countries that were not members of the group, after fulfilling specific requirements incorporated by Basel II. 
recommendations on the management of liquidity and no effective market discipline.

\subsection{Basel Accord III}

As Basel I and II were initiatives of the G10, Basel III was the response to the financial crisis and introduced the Financial Stability Board (FSB) as an institutional innovation ${ }^{2}$. Another novelty was the inclusion of members of the $\mathrm{G} 20^{3}$, because the financial crisis highlighted the need for the participation of other forums, as was the case with emerging countries. All these initiatives contributed to improve the legitimacy of the Committee as a forum for developing global prudent standards.

However, Basel III does not replace Basel II. That is, that the most important element of Basel II, the prudent and supervisory process, is not altered, nor the three-pillar structure. Basel III only changed some of its rules introducing new prudent tools. The new agreement grouped the following measures: (i) improve the quality of capital to absorb losses more adequately; (ii) reduce the risk of the capital framework; (iii) increase minimum capital levels, with an increment in the minimum common equity from $2 \%$ to $4.5 \%$ and the introduction of a conservation buffer and a countercyclical one; (iv) require a leverage ratio as a reinforcement to solvency, based on the risk, to contain excessive leverage in the banking system; (v) improve the standards supervisory process (Pillar II) and market discipline (Pillar III); (vi) create a ratio of short-term liquidity and net stable funding ratio for the long term.

But most important to highlight in our paper is that the main objective of Basel III is to increase and improve the capacity to absorb the consequences of the processes of financial stress, and thus reduce the risk of contagion from the financial sector to the whole economic system.

\subsection{Have achieved their objectives Basel I, II and III?}

In the light of the financial crisis of the past 20 years starting with Mexico in 1994 ("tequila effect"), to which began in the United States in mid-2007 as a result of the collapse of the financial bubble, there are doubts about the effectiveness that the Basel agreements had to support banks during financial storms over the years of its implementation. We observe in Figure 5.

Based on the foregoing, we consider it is urgent to present an alternative solution for financial institutions to face any future crisis with real solvency. In this sense, this article proposes a technically valid option. But it requires the willingness of bankers to undertake a pragmatic solution, and not use more convoluted formulas of financial engineering that lead to a merely virtual solvency.

\section{Stress Test of November 2014 to Spanish banks}

\subsection{Objectives of the Stress Test}

\footnotetext{
${ }^{2}$ Financial Stability Board (FSB), founded in April 2009 as a continuation of the Financial Stability Forum, brings together national authorities (central banks, supervisors and treasury departments), international financial institutions, international groups of regulators and supervisors and the European Central Bank. Its purpose is to promote international financial stability through information exchange and cooperation in financial supervision and surveillance.

3 In 2009, the Basel Committee doubled its size to include 27 institutions, represented by 44 officials from central banks and supervisory bodies.
}

The main objectives of the stress test were to: (i) evaluate the ability of the banking system to withstand adverse scenarios; that is, equity should be higher than the probable deterioration of the asset and simultaneously to respond to savers and investors; (ii) provide transparency to the market; (iii) to set up the additional capital required to ensure solvency in stressed scenarios.

In Europe 130 financial entities participated, of which 15 were Spanish: Banco Financiero y de Ahorros, Banco de Bilbao y Vizcaya Argentaria, Bankinter, Banco Mare Nostrum, Banco de Sabadell, Cajas Rurales Unidas Sociedad Cooperativa, Cataluña Banco, Caja de Ahorros y M.P. Zaragoza, Aragón y Rioja, Kutxabank, Caja de Ahorros y Pensiones de Barcelona, Liberbank, NCG Banco, Banco Popular Español, Banco Santander and Unicaja Banco. Except for Liberbank, they have approved all of the above conditions, from which therefore, a solid economic and financial situation of the Spanish banking system could be deduced. However, according to the financial statements as at December 31, 2011, Spanish banking was in deep trouble. And in less than three years, it would have to take an incredible change of 180 degrees. This, at least, was doubtful. Table 1 shows the consolidated financial statements of Spanish banks as at December 31, 2011.

We said above that "the Spanish banking was in deep trouble", because if it is estimated that the bad debt portfolio amounted to only $15 \%-125.007 .649$ thousands of Euros- this amount was negative in relation to the equity and it would have meant the collapse of the Spanish banking system. But even worse, it was considered likely that the so-called "toxic assets" -bad portfoliorepresented a percentage higher than $15 \%$.

Faced with this serious situation, the Government that took office at the end of 2011, announced on June 9, 2012 that it was obtaining a loan of 100,000,000 thousand Euros from the European Union to rescue the Spanish financial system. These funds were used primarily to clean up some savings entities. Of the 100,000,000 thousands, 40,000,000 thousands were used. And this amount, as always, will be paid by all taxpayers of the country.

\subsection{Results of the stress tests}

Table 2 presents a summary of the results of stress tests related to the solvency ratio. It is important to remember that the CET 1 is the central measure of the financial strength of a bank, whose formula is:

Capital level 1

$$
\text { CET } 1 \text { = }
$$

In the numerator, about 23 economic and financial concepts are combined, while in the denominator, about $10^{4}$ interact. That is, the end result is the product of a dense and convoluted financial engineering. But, from our point of view, the basic problem is that the requirement of $8 \%$ would be insufficient, due to scarcity of a quantitative numerator of the formula.

While it is true that Basel II recommended no limit "to raise capital to the increased risks that banks face, but other measures were necessary, such as strengthening risk management, strengthening the level of provisions and reserves, and improving internal controls", it is clear that in view of everything that happened in the global financial system during the last financial crisis, these recommendations failed. So, why does it still require a percentage equal to or greater than $8 \%$, if it

\footnotetext{
${ }^{4}$ Source: Bank of Spain

http://www.bde.es/f/webbde/GAP/Secciones/SalaPrensa/ComunicadosB CE/NotasInformativasBCE/14/Arc/Fic/plantilla.pdf
} 
has been insufficient to deal with the crisis? Are financial markets, customers, investors and creditors of a bank calmer if the solvency ratio is greater than $8 \%$ ?

\section{Iv. Our alternative proposal}

\subsection{Solvency, Leverage and Assets financed by equity ratios}

The formulas that indicate the solvency, leverage and assets financed by equity of Spanish banks, as well as their evolution from 2010 to 2014, are shown below:

\begin{tabular}{|c|c|c|}
\hline \multirow[b]{2}{*}{ 4.1.1. Solvency } & \multirow[b]{2}{*}{$=$} & Equity \\
\hline & & Total Liability \\
\hline \multirow{2}{*}{ 4.1.2. Leverage } & \multirow{2}{*}{$=$} & Total Liability \\
\hline & & Equity \\
\hline \multirow{2}{*}{\multicolumn{2}{|c|}{ 4.1.3. Equity ratio = }} & Equity \\
\hline & & Total assets \\
\hline
\end{tabular}

\subsubsection{Comments}

It is noted that, during the 14 years studied, there was a slight improvement of the three ratios. For example, in Figure 6, the solvency indicator has increased from $7.6 \%$ to $10.4 \%$. However, the reality is that the equity of the banks has not set up a base that provides security to creditors during financial storms. Therefore, it seems clear that it is rather low; moreover, all the financial engineering presented serves only as a façade of the solvency of the entities and is designed to pass the stress test. Obviously, it is more comfortable, and cheaper, to devise and recommend formulas instead of integrating more equity.

4.1.5. Some sophistries of the Committee of Basel Banking Supervision (CBBS)

Since significant levels of the Basel Committee stated that the concept of regulatory capital in banking is different from the equity of other companies. Therefore, the CBBS, to define regulatory capital, adopted a different perspective. It noted that "since the function of the equity is to ensure the stability of the entity even in very adverse scenarios, the question is whether banks can contribute or not to that aim... With this approach, the equity of the banks will be: capital and reserves; but also those accounts representing gains may not have registered in the reserves ... or certain liabilities that have a dilated (or perpetual) term, or the possibility of suspending repayments in certain circumstances, that permit holders to impose moratoriums on their rights ... ".

With the above criteria, what would happen if every company fits the criteria of sufficiency of its equity from a "different perspective". It could be the start of an irreversible path towards breaching international accounting standards. Therefore, the above mentioned by the CBBS is a series of fallacies about the equity, which has fallen at the times when it really should have demonstrated its effectiveness and solvency.

\subsection{Alternative proposal}

Facing the above exposure, how much should be a sufficient equity? It is known that lending banks require the borrowers -in addition to other financial, technical, legal and environmental requirements- specific indicators for the assets financed with equity. For instance, for factories, railway companies, etc., 50\%; water service, energy, etc., $40 \%$; commercial companies, airlines, etc., 30\%; and service companies, $25 \%$.

So, why do not banks increase their equity to, for example, $15 \%$ of their total assets? They could, say, integrate these funds gradually over five years. Herein is our proposal presented in Table 3 and the following observations provide clarifications about the fore mentioned table.

a. Growth in total assets ${ }^{5}$ of $2.9 \%, 2.5 \%, 2.0 \%, 1.8 \%$ and $1.6 \%$, for the years 2015, 2016, 2017, 2018 and 2019 respectively are estimated.

b. The "Capital Increase" to be carried out gradual and annually by the banks, with its counterpart in the "New assets" account.

c. The capital increases will improve the ratio from $10.6 \%$, in 2015 , to $15 \%$, in 2019 , a percentage that matches our alternative proposal.

In addition, and not the least important, this proposed capital increase would be a demonstration of reciprocity on the part of the Spanish banking system to the taxpayers, who will pay the 40,000,000 thousands Euros mentioned in section 2.1.

\section{v. Conclusions}

The summary of the capital increases is observed in the Table 4 . Also in Figure 9, the gradual increase in the ratio of assets financed with equity from the current $9 \%$ to $15 \%$ would be achieved by the increases referred in 2019 .

The implementation of our proposal depends on:

(i) The enactment of new recommendations by the Committee of Basel Banking Supervision.

(ii) These guidelines, within the European Union framework, will involve the modification of Directive 2013/36/EU (CRD IV) and the EU Regulation N ${ }^{\mathrm{r}}$ 575/2013 (RRC) related to capital requirements.

(iii) And finally, and perhaps most importantly and difficult, of the willingness and goodwill of bankers.

Regarding this last item (iii), it is important to mention that the Spanish banking market is an oligopoly dominated by two large institutions, Banco Bilbao y Vizcaya Argentaria (BBVA) and Banco Santander. Between them both, they must represent a total of 219,754,338 thousands Euros, i.e., $62.1 \%$ of all capital increases, 354,000,000 thousands Euros. And among the big five -BBVA, Santander, Sabadell, Popular and Bankinter310.274.347 thousands Euros, i.e., 87.6\%.

In conclusion, the solvency of the Spanish banking system which undoubtedly can be extrapolated to the European- in order to acquire strength, endurance and real stability to resist a future financial crisis, needs to strengthen the numerator of the formula of the solvency ratio -and thus the "Tier 1"- through gradual capital increases.

${ }^{5}$ Source: Ministry of Economy and Competitiveness of Spain, 2015 and 2016. The growth rates for the years 2017, 2018 and 2019, were estimated by the authors based on likely changes that could occur in the Spanish political scene, from December 2015. 
Proc. of the Third Intl. Conf. on Advances in Management, Economics and Social Science - MES 2015.

Copyright (c) Institute of Research Engineers and Doctors, USA .All rights reserved.

ISBN: 978-1-63248-081-1 doi: 10.15224/ 978-1-63248-081-1-86

\section{Abbreviations and Acronyms}

$\mathrm{AQR}=$ Assets Quality Review

BIS $=$ Bank for International Settlements

CBBS $=$ Committee of Basel Banking Supervision

CET 1 = Common Equity Tier 1

EBA = European Banking Association

FSB $=$ Financial Stability Board

GDP $=$ Gross domestic product

RWA $=$ Risk Weighted Average

\section{Figures}

Fig. 1

Basel I Structure

Basel I

Capital definition

Risk Weighted Assets

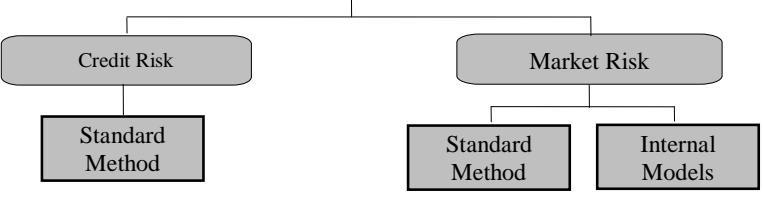

Source: Millán de la L., J.R. y Fruet-C., J.V. 2012. Supervisión bancaria internacional. Una doble visión BIS y EBA.

Fig. 2

Solvency ratio of Basel I

RWA $\left\{\begin{array}{l}\text { Regulatory Capital } \\ \text { Market risk } \\ + \text { Credit risk } \\ + \text { Operational risk }\end{array}\right.$

Source: Millán de la L., J.R. y Fruet-C., J.V. 2012. Supervisión bancaria internacional. Una doble visión BIS y EBA.

Fig. 3

Basel II Structure

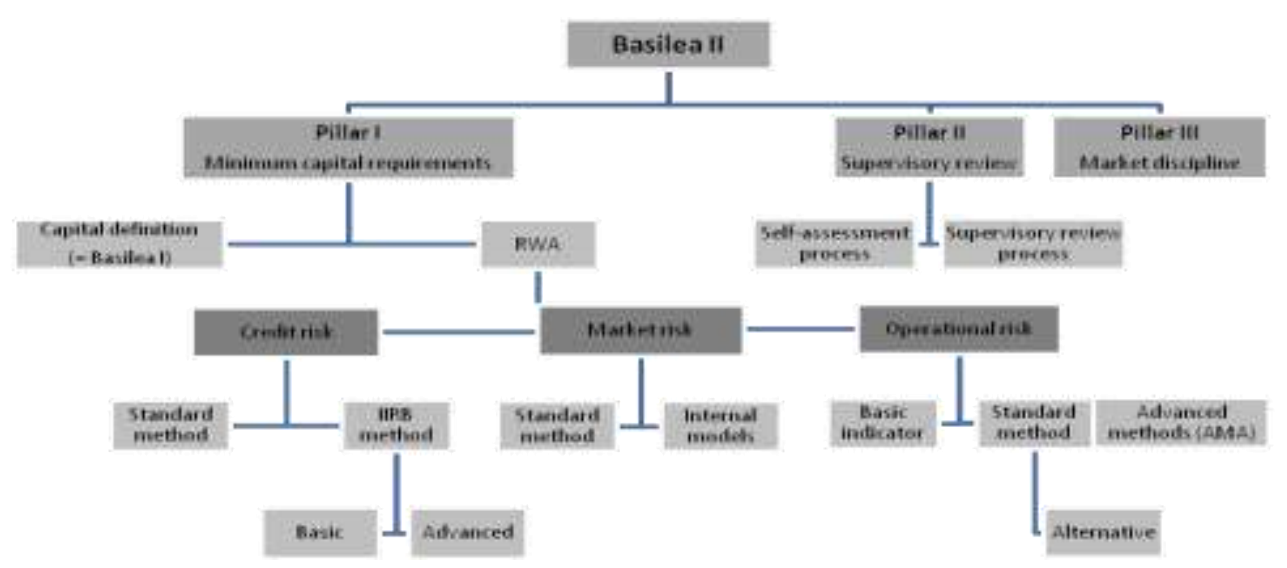

Source: Millán de la L., J.R. y Fruet-Cardozo, J.V. 2012. Supervisión bancaria internacional. Una doble visión BIS y EBA.

${ }^{6}$ Incorporated by Basel II. 
Proc. of the Third Intl. Conf. on Advances in Management, Economics and Social Science - MES 2015.

Copyright (c) Institute of Research Engineers and Doctors, USA .All rights reserved.

ISBN: 978-1-63248-081-1 doi: 10.15224/ 978-1-63248-081-1-86

Fig. 4

Basel I, II and III vs. Financial crisis

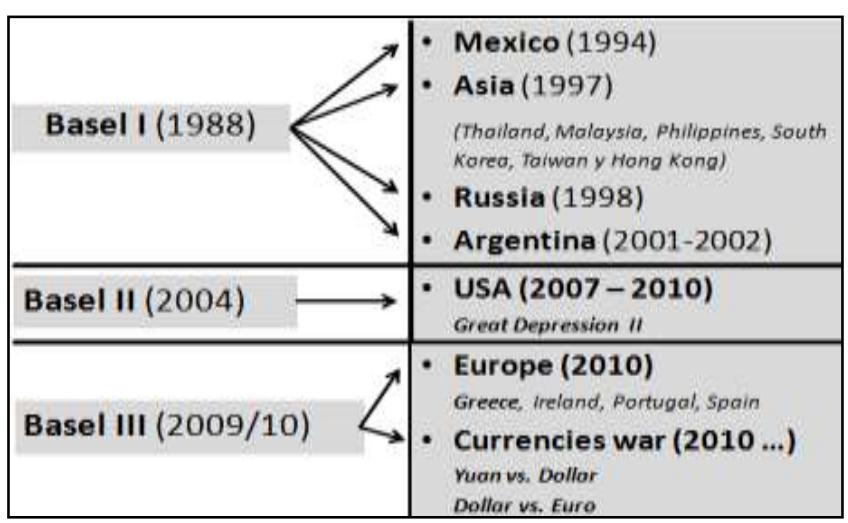

Source: Prepared by the authors

Fig. 5

Solvency ratio of Spanish Banks - 2000 to 2014

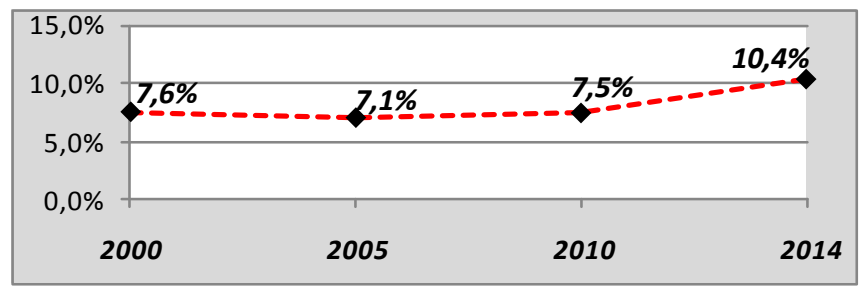

Fig. 6

Leverage ratio of Spanish banks - 2000 to 2014

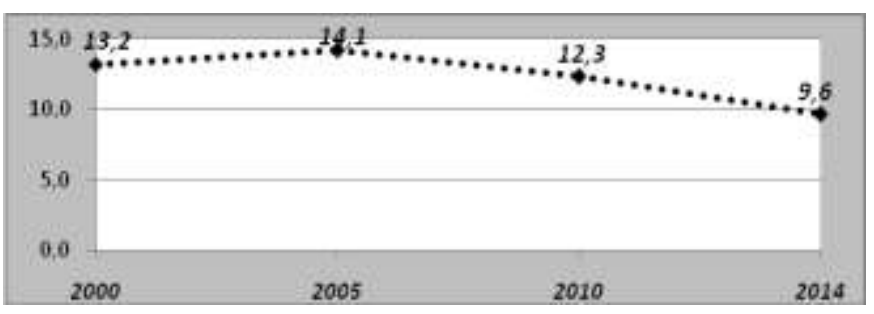

Fig. 7

Equity ratio

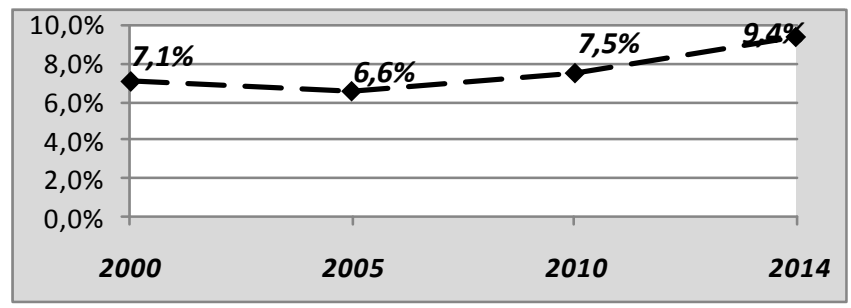

Source: Graphs prepared by the authors on the basis of the financial statements of Spanish banks (2000-2014), published by the Bank of Spain.
Fig. 8

Gradually increasing the Equity ratio

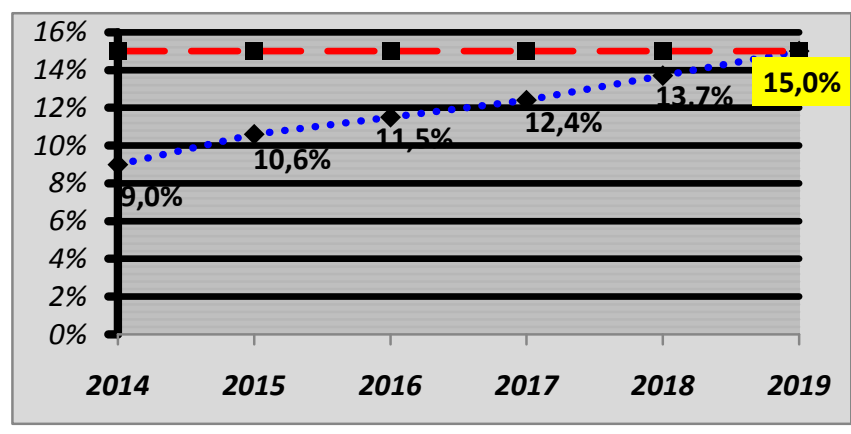


Proc. of the Third Intl. Conf. on Advances in Management, Economics and Social Science - MES 2015.

Copyright $(\odot$ Institute of Research Engineers and Doctors, USA .All rights reserved.

ISBN: 978-1-63248-081-1 doi: 10.15224/ 978-1-63248-081-1-86

\section{Tables}

TABLE 1

Comparative scheme between Basel I and II

\begin{tabular}{|c|c|c|}
\hline & Basel I & Basel II \\
\hline Minimum capital ratio & $8 \%$ & \\
\hline Capital definition & Tier $1^{7}+$ Tier $2^{8}$ & \\
\hline Market risk & Amendment 1996 & \\
\hline $\begin{array}{l}\text { Denominator of } \\
\text { the ratio }\end{array}$ & $\begin{array}{l}\text { Weighted assets } \\
\text { based on broad } \\
\text { categories of } \\
\text { credit }\end{array}$ & $\begin{array}{l}\text { For credit risk, assets } \\
\text { are weighted based on: } \\
\begin{array}{ll}\text { External ratings } \\
\text { agencies as much }\end{array} \\
\text { risk category. } \\
\text { b. } \begin{array}{l}\text { Internal models } \\
\text { of institutions. }\end{array}\end{array}$ \\
\hline Change & & $\begin{array}{l}\text { Operational risk in the } \\
\text { denominator }\end{array}$ \\
\hline Change & & $\begin{array}{l}\text { Banking supervisory } \\
\text { process (Pillar I). }\end{array}$ \\
\hline Change & & $\begin{array}{l}\text { Market discipline } \\
\text { (Pillar II). }\end{array}$ \\
\hline
\end{tabular}

Source: Millán de la L., J.R. y Fruet-C., J.V. 2012. Supervisión bancaria internacional. Una doble visión BIS y EBA.

TABLE 2

Consolidated financial statements of Spanish banks at December 31, 2011 (Thousands of $\epsilon$ )

\begin{tabular}{|l|r|l|r|}
\hline Portfolio & 833.384 .328 & Equity & 119.420 .927 \\
\hline Other Assets & 695.043 .930 & Liabilities & 1.409 .007 .331 \\
\hline Total Assets & $\mathbf{1 . 5 2 8 . 4 2 8 . 2 5 8}$ & $\begin{array}{l}\text { Equity \& } \\
\text { Liabilities }\end{array}$ & $\mathbf{1 . 5 2 8 . 4 2 8 . 2 5 8}$ \\
\hline
\end{tabular}

Source: Table prepared by the authors on the basis of data from the Bank of Spain
TABLE 3

Results of the stress test of Spanish financial entities Numbers in percentages (\%)

\begin{tabular}{|c|c|c|c|}
\hline Financial entity & $\begin{array}{c}\text { Bco. } \\
\text { Financiero }\end{array}$ & BBVA & Bankinter \\
\hline CET1 adjusted by $A Q R^{9}$ & 10,60 & 10,54 & 11,67 \\
\hline CET1 adjusted base scen. ${ }^{10}$ & 12,33 & 10,24 & 11,63 \\
\hline CET1 adjusted adv. scen. ${ }^{11}$ & 10,30 & 8,97 & 10,80 \\
\hline
\end{tabular}

\begin{tabular}{|l|c|c|c|}
\hline $\begin{array}{c}\text { Financial entity Ratio } \\
\text { CET1 adjusted by AQR }\end{array}$ & BMN & $\begin{array}{c}\text { Banco } \\
\text { Sabadell }\end{array}$ & $\begin{array}{c}\text { Cajas Rura- } \\
\text { les Unidas }\end{array}$ \\
\hline CET1 adjusted base scen. & 10,01 & 10,26 & 9,95 \\
\hline CET1 adjusted adv. scen. & 8,09 & 10,16 & 10,17 \\
\hline
\end{tabular}

\begin{tabular}{|l|c|c|c|}
\hline \multicolumn{1}{|c|}{ Rinancial entity } & $\begin{array}{c}\text { Cataluña } \\
\text { Banco }\end{array}$ & $\begin{array}{c}\text { Caja } \\
\text { Zaragoza }\end{array}$ & $\begin{array}{c}\text { Kutxa- } \\
\text { bank }\end{array}$ \\
\hline CET1 adjusted by AQR & 12,21 & 10,01 & 12,03 \\
\hline CET1 adjusted base scen. & 11,76 & 10,31 & 12,36 \\
\hline CET1 adjusted adv. scen. & 8,02 & 7,82 & 11,82 \\
\hline
\end{tabular}

\begin{tabular}{|l|c|c|c|}
\hline \multicolumn{1}{|c|}{ Financial entity } & $\begin{array}{c}\text { Caja de } \\
\text { Barcelona }\end{array}$ & Liberbank & $\begin{array}{c}\text { NCG } \\
\text { Bank }\end{array}$ \\
\hline CET1 adjusted by AQR & 10,24 & $7,82^{12}$ & 10,18 \\
\hline CET1 adjusted base scen. & 10,79 & 8,51 & 11,50 \\
\hline CET1 adjusted adv. scen. & 9,25 & 5,62 & 9,14 \\
\hline
\end{tabular}

\begin{tabular}{|l|c|c|c|}
\hline $\begin{array}{c}\text { Financial entity } \\
\text { Ratio }\end{array}$ & $\begin{array}{c}\text { Banco } \\
\text { Popular }\end{array}$ & $\begin{array}{c}\text { Banco } \\
\text { Santander }\end{array}$ & $\begin{array}{c}\text { Unicaja } \\
\text { Banco }\end{array}$ \\
\hline CET1 adjusted by AQR & 10,08 & 10,34 & 10,88 \\
\hline CET1 adjusted base scen. & 10,20 & 11,05 & 11,12 \\
\hline CET1 adjusted adv. scen. & 7,56 & 8,95 & 8,89 \\
\hline
\end{tabular}

${ }^{9}$ Common Equity Tier of level 1 (CET1) adjusted by the Assets Quality Review (AQR).

${ }^{10}$ The base scenario means a "normal" situation for Spain. The parameters are: (i) GDP, an increase of $1 \%$ for $2014,1.7 \%$ for 2015 and $2.2 \%$ for 2016 was expected. (ii) Unemployment rate: $25.7 \%$ for 2014 ; $24.6 \%, 2015$ y $23.2 \%$ for 2016 . (iii) Inflation rate, $0.3 \%$ for $2014,0.9 \%$, in 2015 and $1.3 \%$ in 2016. House prices: a decrease of $8.7 \%$ in 2014 and $14 \%$ in 2015 and 2016.

${ }^{11}$ An adverse scenario would be: (i) GDP, a contraction of $0.3 \%$ in 2014, $1 \%$ in 2015 and a small $0.1 \%$ growth in 2016. (ii) Unemployment rate, up to $26.3 \%$ in $2014,26.8 \%$ in 2015 and $27.1 \%$ in 2016. (iii) Inflation rate, would remain at very low levels, $0.3 \%$ in $2014,0.4 \%$ in 2015 and $0.8 \%$ in 2016. Housing prices, a light reduction of $3.1 \%$ in 2014 and $5 \%$ in 2015 and 2016. (v) Interest rate of treasury bonds 10-years would rise again to 5.7\%. (In August 2012 reached 7.2\% in the secondary market).

${ }^{12}$ Liberbank was the only failed entity, because its mark was less than $8 \%$. 
Proc. of the Third Intl. Conf. on Advances in Management, Economics and Social Science - MES 2015.

Copyright (C) Institute of Research Engineers and Doctors, USA .All rights reserved.

ISBN: 978-1-63248-081-1 doi: 10.15224/ 978-1-63248-081-1-86

TABLE 4

\section{Estimated consolidated balance sheets of Spanish banks}

December 2015 to December 2019

\begin{tabular}{|c|c|c|c|c|c|}
\hline \multicolumn{6}{|c|}{ FINANCIAL STATEMENTS - December 31, 2014} \\
\hline & Thousands $€$ & $\%$ & & Thousands $€$ & $\%$ \\
\hline Portfolio & 732.552 .419 & $50,5 \%$ & Equity & 136.301 .019 & $9,4 \%$ \\
\hline Other Assets & 718.283 .650 & $49,5 \%$ & Capital Increase & 0 & $0,0 \%$ \\
\hline \multirow[t]{2}{*}{ New Assets } & & & Total Equity & 136.301 .019 & $9,4 \%$ \\
\hline & & & Liability & 1.314 .535 .050 & $90,6 \%$ \\
\hline Total Assets & 1.450 .836 .069 & $100,0 \%$ & $\begin{array}{l}\text { Total Equity \& } \\
\text { Liability }\end{array}$ & 1.450 .836 .069 & $100,0 \%$ \\
\hline
\end{tabular}

Source: Prepared by the authors on the basis of data from the Bank of Spain

\begin{tabular}{|l|r|r|l|r|c|}
\hline \multicolumn{7}{|c|}{ FINANCIAL STATEMENTS - December 31, 2015 } \\
\hline & Thousands $€$ & $\%$ & & \multicolumn{1}{|c|}{ Thousands $€$} & \multicolumn{1}{c|}{$\%$} \\
\hline \multirow{2}{*}{ Portfolio } & 753.796 .439 & $49,7 \%$ & Equity & 136.301 .019 & $9,0 \%$ \\
Other Assets & 739.113 .876 & $48,7 \%$ & Capital Increase & 25.000 .000 & $1,6 \%$ \\
New Assets & 25.000 .000 & $1,6 \%$ & Total Equity & 161.301 .019 & $\mathbf{1 0 , 6 \%}$ \\
& & & Liability & 1.356 .609 .296 & $89,4 \%$ \\
\cline { 2 - 7 } & & & Total Equity \& & $\mathbf{1 . 5 1 7 . 9 1 0 . 3 1 5}$ & $\mathbf{1 0 0 , 0 \%}$ \\
\hline
\end{tabular}

FINANCIAL STATEMENTS - December 31, 2016

\begin{tabular}{|c|c|c|c|c|c|}
\hline \multicolumn{6}{|c|}{ FINANCIAL STATEMENTS - December 31, 2016} \\
\hline & Thousands $€$ & $\%$ & & Thousands $€$ & $\%$ \\
\hline Portfolio & 772.641 .350 & $49,1 \%$ & Equity & 136.301.019 & $8,7 \%$ \\
\hline Other Assets & 757.591 .723 & $48,1 \%$ & Capital Increase & 44.000 .000 & $2,8 \%$ \\
\hline New Assets & 44.000 .000 & $2,8 \%$ & Total Equity & 180.301 .019 & $11,5 \%$ \\
\hline & & & Liability & 1.393.932.054 & $88,5 \%$ \\
\hline Total Assets & 1.574.233.073 & $100,0 \%$ & $\begin{array}{l}\text { Total Equity \& } \\
\text { Liability }\end{array}$ & 1.574.233.073 & $100,0 \%$ \\
\hline
\end{tabular}

\begin{tabular}{|l|r|r|l|r|c|}
\hline \multicolumn{7}{|c|}{ FINANCIAL STATEMENTS - December 31, 2017 } \\
\hline & Thousands $€$ & $\%$ & & \multicolumn{1}{|c|}{ Thousands $€$} & $\%$ \\
\hline Portfolio & 788.094 .177 & $48,5 \%$ & Equity & 136.301 .019 & $8,4 \%$ \\
Other Assets & 772.743 .557 & $47,5 \%$ & Capital Increase & 65.000 .000 & $4,0 \%$ \\
New Assets & 65.000 .000 & $4,0 \%$ & Total Equity & 201.301 .019 & $\mathbf{1 2 , 4 \%}$ \\
& & & Liability & 1.424 .536 .715 & $87,6 \%$ \\
\cline { 2 - 7 } & & \multicolumn{7}{|c|}{ Total Equity $\mathbf{\&}$} & $\mathbf{1 . 6 2 5 . 8 3 7 . 7 3 4}$ & $\mathbf{1 0 0 , 0 \%}$ \\
\hline
\end{tabular}

\begin{tabular}{|c|c|c|c|c|c|}
\hline \multicolumn{6}{|c|}{ FINANCIAL STATEMENTS - December 31, 2018} \\
\hline & Thousands $€$ & $\%$ & & Thousands $€$ & $\%$ \\
\hline Portfolio & 802.279 .872 & $47,6 \%$ & Equity & 136.301 .019 & $8,1 \%$ \\
\hline Other Assets & 786.652 .941 & $46,7 \%$ & Capital Increase & 95.000 .000 & $5,6 \%$ \\
\hline New Assets & 95.000 .000 & $5,6 \%$ & Total Equity & 231.301.019 & $13,7 \%$ \\
\hline & & & Liability & 1.452 .631 .795 & $86,3 \%$ \\
\hline Total Assets & 1.683 .932 .814 & $100,0 \%$ & $\begin{array}{l}\text { Total Equity \& } \\
\text { Liability }\end{array}$ & 1.683 .932 .814 & $100,0 \%$ \\
\hline
\end{tabular}

\section{FINANCIAL STATEMENTS - December 31, 2019}

\begin{tabular}{|c|c|c|c|c|c|}
\hline \multicolumn{6}{|c|}{ FINANCIAL STATEMENTS - December 31, 2019} \\
\hline & Thousands $€$ & $\%$ & & Thousands $€$ & $\%$ \\
\hline Portfolio & 815.116 .350 & $46,9 \%$ & Equity & 136.301 .019 & $7,8 \%$ \\
\hline Other Assets & 799.239.388 & $46,0 \%$ & Capital Increase & 125.000 .000 & $7,2 \%$ \\
\hline New Assets & 125.000 .000 & $7,2 \%$ & Total Equity & 261.301 .019 & $15,0 \%$ \\
\hline & & & Liability & 1.478 .054 .720 & $85,0 \%$ \\
\hline Total Assets & 1.739.355.739 & $100,0 \%$ & $\begin{array}{l}\text { Total Equity \& } \\
\text { Liability }\end{array}$ & 1.739.355.739 & $100,0 \%$ \\
\hline
\end{tabular}

TABLE 5

Total of proposed capital increases -2015 to 2019

\begin{tabular}{|c|c|c|}
\hline Years & $\begin{array}{c}\text { Growth rates } \\
(\boldsymbol{\%})\end{array}$ & $\begin{array}{c}\text { Capital increases } \\
\text { (Thousands } \boldsymbol{€})\end{array}$ \\
\hline 2015 & 2.90 & $25,000,000$ \\
\hline 2016 & 2.50 & $44,000,000$ \\
\hline 2017 & 2.00 & $65,000,000$ \\
\hline 2018 & 1.80 & $95,000,000$ \\
\hline 2019 & 1.60 & $125,000,000$ \\
\hline \multicolumn{2}{|c|}{ Total } & $\mathbf{3 5 4 , 0 0 0 , 0 0 0}$ \\
\hline
\end{tabular}

Source: Prepared by the authors. The growth rates for the years 2015 and 2016 are based on the Ministry of Economy and Competitiveness of Spain. For years 2017, 2018 and 2019, they were estimated by the authors based on likely changes that could occur in the Spanish political scene, from December 2015 onwards.

\section{References}

[1] Alfaro, R. and Grehmann, M. (2009), Macro stress test and crisis: What can we learn? BIS Quaterly Review. Basel, Switzerland, December, pp. 29-41

[2] Borio, C. and Drehmann, M. (2011), Towards an operational framework for financial stability: Fuzzy? Measurement and its consequences, in financial stability, monetary policy and central banking. Central Bank of Chile. Santiago, Chile.

[3] Calvo, J. (2010), Manual del sistema financiero español. Editorial Ariel Economía. 22 ${ }^{\text {nd }}$ edition, Madrid, Spain, pp. 255-256

[4] Ibáñez, J. (2011), Los nuevos requisitos regulatorios de Basilea: contenido, justificación económica e impacto sobre el negocio bancario. Mediterráneo económico $\mathrm{n}^{\mathrm{r}} 19$. Fundación Cajamar, Almería, Spain, pp. 159

[5] Martín, J.L. and Téllez, C. (2009), La regulación y supervisión del sistema financiero ante la crisis económica. Boletín de Estudios Económicos. Vol. LXIV - $\mathrm{N}^{\mathrm{r}} 198-$ Universidad de Deusto, Bilbao, Spain, December, pp. 441468

[6] Millán de la Lastra, J. R. and Fruet-Cardozo, J. V. (2012), Supervisión bancaria internacional. Una doble visión BIS y EBA. Bohodón Ediciones S.L., Madrid, Spain, pp. 37-39; 49-83; 99-118

[7] Millán de la Lastra, J.R. (2012), Pruebas de resistencia del sistema financiero europeo: Retrospectiva del año 2011. Boletín de Estudios Económicos. Vol. LXVII - $\mathrm{N}^{\mathrm{r}} 206$, Universidad de Deusto, Bilbao, Spain, August, pp. 413-418

\section{Webpages}

[8] Bank of Spain

http://www.bde.es/f/webbde/GAP/Secciones/SalaPrensa/Co municadosBCE/NotasInformativasBCE/14/Arc/Fic/plantilla .pdf

http://www.bde.es/webbde/es/secciones/informes/banota/b1 20831.pdf

[9] European Banking Authority (EBA)

http://www.eba.europa.eu/-/eba-publishes-2014-eu-widestress-test-results

http://www.eba.europa.eu/documents/10180/669262/2014+ EU-wide+ST-aggregate+results.pdf

[10] Ministry of Economy and Competitiveness of Spain http://www.mineco.gob.es/portal/site/mineco/economia

[11] Spanish Banking Association http://www.aebanca.es/EstadosFinancieros/index.htm 